\title{
FINANCIAL PERFORMANCE ANALYSIS OF CONSTRUCTION INDUSTRY: CASE STUDY OF PT. NINDYA KARYA (PERSERO) IN PERIOD OF 2011 - 2015
}

\author{
Wiwiek Mardawiyah Daryanto ${ }^{1}$, Popy Oktaviabri Hestiwati ${ }^{2}$
}

1 Sekolah Tinggi Manajemen IPMI, Jakarta, Indonesia

2 Sekolah Bisnis dan Manajemen ITB, Bandung, Indonesia

Article Information

Received: 17 March 2020

Accepted: 27 May 2020

Published: 6 July 2020

DOI: $10.33555 /$ ijembm.v7i2.128

Corresponding Author:

Wiwiek Mardawiyah Daryanto Jakarta, Indonesia

Email: wiwiek.daryanto@ipmi.ac.id

ISSN 2338-8854

eISSN 2620-9918

\begin{abstract}
Financial performance plays an important role in assessing the condition of one company, whether they are healthy or not. Every State-Owned Enterprise has an obligation to report their financial condition in reference to the Decree of Indonesia's Ministry of Stated-Owned Enterprises No. KEP-100/MBU/2002 regarding health valuation. This study aims to investigate the performance of PT. Nindya Karya (Persero) in eyes of their financial aspect from period of 2011 to 2015. Financial Ratio Analysis (FRA) technique was used as a tool to observe the condition. Company's published annual reports data were taken into a data collection. By utilizing the eight chosen FRA ratios, the result of the study shows good trends, meaning that it classified as Healthy condition. However, in 2011 the scoring of indicated a Less Healthy condition, which is happening due to the lowest net income compared to the other years. In other words, the company suffers from losses in the high competition between the contractors. Additionally, the result showed a significantly increased in its ratio from 2011 to 2015. This indicates that the company made an effort in improving their competencies in the globalization era. This study will beneficial the company in determining their next strategies for the future references.
\end{abstract}

Keywords: Profitability, Liquidity, Activity, Solvency, Financial Performance 


\section{Introduction}

Construction industry is considered as one of the most important business sectors that support the economic growth in Indonesia. After the inauguration of ASEAN Economic Community (AEC) in ends of 2015, the more competitive markets will emerge. This is due to the AEC's objective which is to uniting an ASEAN (Association of Southeast Asian Nations) countries member as one market without any barriers. In other words, it allows foreign companies to go in and out in other country to trade their product and services.

In this economic globalization, it is essential to have a performance measurement. Many advantages can be obtained through having a measurement. One of them is to push the company to do process improvement and increase their productivity and effectiveness to compete with the national or even international field. Performance evaluation can be done in several methods. For instance, in financial aspect, Financial Ratio Analysis (FRA) can be used to give a big picture in company's financial condition to classify whether they are in a healthy condition or not. This evaluation is performed in order to maintain the sustainable growth of the company and improving their performance in the middle of a tight competition. The private company and the State-Owned Enterprises have an obligation to report their financial activity annually. From that financial report, the company's performance can be determined through its balance sheet and income statement. The method of FRA often being used as it can measure the company's performance over time using the changes trend analysis.

Over any industries have been implementting this kind of methodology, especially construction industry. In addition, it can also use comparative analysis in the average standard measurement of the construction industry. One of their industry's players is PT. Nindya Karya (Persero). PT Nindya
Karya is a state-owned enterprise where it is owned $99 \%$ by PT. PPA (Persero) and 1\% by the government of Indonesia. The company works in the field of construction. It has a purpose and objectives in of the establish-ment of building planning, contracting, and supervision of the building construction. Until 2015, the business activities that they are doing including construction services including technical or design planning, development work, project management and procurement.

\section{Development of the Industry}

Construction industry generates a service based infrastructure and physical facility. The services included study activity, technical planning and design, and implementtation as well as controlling. Construction field also has an important role in providing jobs. Based on the government statement, construction service industry faces a severe problem that need to be solved as the beginning of the ASEAN Economic Community (AEC) that provides trading without barriers for ASEAN countries members. Indonesia is the biggest construction market in ASEAN and because of that reason; the construction market in Indonesia will attract foreign construction industry to enter it. The more presence of foreign players yields the higher level of its competition among that industry, especially for locals.

The opportunity to obtain profit in the construction industry was quite big. A limited market will produce unfair competition between them. This is where the support from the government is required. It also applied to improve the lower to middle companies to be able to compete in the market. As the domestic market is currently has dominated by a large company. According to Soenarno (2003), there are 3 (three) major problems that being experienced by construction industry in Indonesia. The first one is productivity, the second is financial and the last was the technology. 


\section{Methodology}

This research adapted a secondary analysis in quantitative method. Descriptive Financial Ratio Analysis (FRA) such as Profitability ratio, Liquidity ratio, Activity ratio and Solvency ratio was used as an assessment tool in illustrating the condition of the company. PT. Nindya Karya (Persero) is a non-financial Stated-Owned Enterprises that characterized into noninfrastructure category. Therefore, those financial ratios were based on the Decree of Indonesia's Ministry of Stated-Owned Enterprises No. KEP-100/MBU/2002 related the soundness's assessment of State-Owned Enterprises (SOE). There are eight chosen indicators to be measured, which are Return on Equity (ROE), Return on Investment (ROI), Cash Ratio, Current Ratio, Collection Periods, Inventory Turnover, Total Asset Turnover (TATO) and Total Equity to Total Asset. All of those indicators will be calculated and the total weight will be assessed to see the financial performance of PT. Nindya Karya (Persero) and the level of its healthiness.

a. Return on Equity (ROE)

$$
R O E=\frac{\text { Net Income }}{\text { Total Equity }} \times 100 \%
$$

Source: The Decree of Ministry of Stated-Owned Enterprise (SOE) No. KEP-100/MBU/2002

b. Return on Investment (ROI)

$$
R O I=\frac{+ \text { Depreciation } x 100 \%}{\text { Capital Employed }}
$$

Where, Capital Employed = Total Asset - Fixed Asset

Source: The Decree of Ministry of Stated-Owned Enterprise (SOE) No. KEP-100/MBU/2002

c. Cash Ratio

Cash Ratio $=\underline{\text { Cash and Cash Equivalent }} \times 100 \%$ Current Liabilities

Source: The Decree of Ministry of Stated-Owned Enterprise (SOE) No. KEP-100/MBU/2002

\section{d. Current ratio}

$$
\text { Current Ratio }=\frac{\text { Current Asset }}{\text { Current Liabilities }} \times 100 \%
$$

Source: The Decree of Ministry of Stated-Owned Enterprise (SOE) No. KEP-100/MBU/2002

e. Collection Periods

$$
\begin{aligned}
& \text { Collection } \\
& \text { Periods }
\end{aligned}=\frac{\text { Total Account Receivable }}{\text { Total Sales Revenue } \div 365 \text { days }}
$$

Source: The Decree of Ministry of Stated-Owned Enterprise (SOE) No. KEP-100/MBU/2002

\section{f. Inventory Turnover}

$$
\begin{aligned}
& \text { Inventory } \\
& \text { Turnover }
\end{aligned}=\frac{\text { Total Inventories }}{\text { Total Sales Revenue } \div 365 \text { days }}
$$

Source: The Decree of Ministry of Stated-Owned Enterprise (SOE) No. KEP-100/MBU/2002

g. Total Asset Turnover

$$
\begin{gathered}
=\text { Total Revenue } \times 100 \% \\
\text { Capital Employed }
\end{gathered}
$$

Source: The Decree of Ministry of Stated-Owned Enterprise (SOE) No. KEP-100/MBU/2002

h. Total Equity to Total Asset

$$
\begin{aligned}
& \text { Total Equity to } \\
& \text { Total Asset }
\end{aligned}=\frac{\text { Total Equity }}{\text { Total Asset }} \times 100 \%
$$

Source: The Decree of Ministry of Stated-Owned Enterprise (SOE) No. KEP-100/MBU/2002

i. The procedure of financial level of healthiness of SOEs

The financial health assessment of StateOwned Enterprises can be seen from its financial aspect using total weight calculation method form the eight indicators that has been measured. 
The indicator's value and the total weight score as being shown in the table below:

Table 1. Health Indicator of SOE

Source: The Decree of Ministry of SOE No. KEP-100/MBU/2002

\begin{tabular}{ccc}
\hline \multicolumn{3}{c}{ Company's Health Indicator } \\
\hline Category & Value & Score \\
\hline Healthy & AAA & $>95$ \\
\hline Healthy & AA & $80<\mathrm{TS} \leq 95$ \\
\hline Healthy & A & $65<\mathrm{TS} \leq 80$ \\
\hline Less Healthy & BBB & $50<\mathrm{TS} \leq 65$ \\
\hline Less Healthy & BB & $40<\mathrm{TS} \leq 50$ \\
\hline Less Healthy & B & $30<\mathrm{TS} \leq 40$ \\
\hline Unhealthy & CCC & $20<\mathrm{TS} \leq 30$ \\
\hline Unhealthy & CC & $10<\mathrm{TS} \leq 20$ \\
\hline Unhealthy & $\mathrm{C}$ & $\mathrm{TS} \leq 10$ \\
\hline
\end{tabular}

In order to assess financial performance aspect, the total weighted score is obtained from summing up the score of 8 financial ratios. Total weighted score of Non Infrastructure company group is 70 (where the pharmaceutical companies belong to). The score is collected from computing financial ratios as below (in the scope of this study, only look at the "Non Infra" column):

Table 2. Return On Equity (ROE)

Score Result from the Computed ROE [21]

\begin{tabular}{ccc}
\hline \multirow{2}{*}{$\operatorname{ROE}(\%)$} & \multicolumn{2}{c}{ Skor } \\
\cline { 2 - 3 } $15<\mathrm{ROE}$ & Infra & Non Infra \\
\hline $13<\mathrm{ROE}<=15$ & 13,5 & 20 \\
\hline $11<\mathrm{ROE}<=13$ & 12 & 18 \\
\hline $9<\mathrm{ROE}<=11$ & 10,5 & 16 \\
\hline $7,9<\mathrm{ROE}<=9$ & 9 & 14 \\
\hline $6,6<\mathrm{ROE}<=7,9$ & 7,5 & 10 \\
\hline $5,3<\mathrm{ROE}<=6,6$ & 6 & 8,5 \\
\hline $4<\mathrm{ROE}<=5,3$ & 5 & 7 \\
\hline $2,5<\mathrm{ROE}<=4$ & 4 & 5,5 \\
\hline $1<\mathrm{ROE}<=2,5$ & 3 & 4 \\
\hline $0<\mathrm{ROE}<=1$ & 1,5 & 0 \\
\hline ROE $<0$ & 1 & 2 \\
\hline
\end{tabular}


Table 3. Return On Investment (ROI)

Score Result from the Computed ROI [21]

\begin{tabular}{ccc}
\hline \multirow{2}{*}{ ROI $(\%)$} & \multicolumn{2}{c}{ Skor } \\
\cline { 2 - 3 } & Infra & Non Infra \\
\hline $18<\mathrm{ROI}$ & 10 & 15 \\
\hline $15<\mathrm{ROI}<=18$ & 9 & 13,5 \\
\hline $13<\mathrm{ROI}<=15$ & 8 & 12 \\
\hline $12<\mathrm{ROI}<=13$ & 7 & 10,5 \\
\hline $10,5<\mathrm{ROI}<=12$ & 6 & 9,5 \\
\hline $9<\mathrm{ROI}<=10,5$ & 5 & 6 \\
\hline $7<\mathrm{ROI}<=9$ & 4 & 5 \\
\hline $5<\mathrm{ROI}<=7$ & 3,5 & 4 \\
\hline $3<\mathrm{ROI}<=5$ & 3 & 2 \\
\hline $1<\mathrm{ROI}<=3$ & 2,5 & 1 \\
\hline $0<\mathrm{ROI}<=1$ & 2 & 0 \\
\hline ROI $<0$ & & 3 \\
\hline
\end{tabular}

Table 4. Cash Ratio

Score Result from the Computed Cash Ratio [21]

\begin{tabular}{ccc}
\hline \multirow{2}{*}{ Cash Ratio $=\mathbf{x}(\%)$} & \multicolumn{2}{c}{ Skor } \\
\cline { 2 - 3 } & Infra & Non Infra \\
\hline $\mathrm{x}>=35$ & 3 & 5 \\
\hline $25<=\mathrm{x}<35$ & 2,5 & 4 \\
\hline $15<=\mathrm{x}<25$ & 2 & 3 \\
\hline $10<=\mathrm{x}<15$ & 1,5 & 2 \\
\hline $5<=\mathrm{x}<10$ & 1 & 1 \\
\hline $0<=\mathrm{x}<5$ & 0 & 0 \\
\hline
\end{tabular}


Table 5. Current Ratio

Score Result from the Computed Current Ratio [21]

\begin{tabular}{ccc}
\hline $\begin{array}{c}\text { Current Ratio }=\mathrm{x} \\
(\boldsymbol{\%})\end{array}$ & Infra & Non Infra \\
\hline $125<=\mathrm{x}$ & 3 & 5 \\
\hline $110<=\mathrm{x}<125$ & 2,5 & 4 \\
\hline $100<=\mathrm{x}<110$ & 2 & 3 \\
\hline $95 \quad<=\mathrm{x}<100$ & 1,5 & 2 \\
\hline $90<=\mathrm{x}<95$ & 1 & 1 \\
\hline $\mathrm{x}<90$ & 0 & 0 \\
\hline
\end{tabular}

Table 6. Collection Periods (CP)

Take the Best Score of Either 2 Variables [21]

\begin{tabular}{|c|c|c|c|}
\hline \multirow{2}{*}{$\begin{array}{c}\mathbf{C P}=\mathbf{x} \\
\text { (hari) }\end{array}$} & \multirow{2}{*}{$\begin{array}{c}\text { Perbaikan }=\mathbf{x} \\
\text { (hari) }\end{array}$} & \multicolumn{2}{|c|}{ Skor } \\
\hline & & Infra & Non Infra \\
\hline$x<=60$ & $x>35$ & 4 & 5 \\
\hline $60<x<=90$ & $30<x<=35$ & 3,5 & 4,5 \\
\hline $90<x<=120$ & $25<x<=30$ & 3 & 4 \\
\hline $120<x<=150$ & $20<x<=25$ & 2,5 & 3,5 \\
\hline $150<x<=180$ & $15<x<=20$ & 2 & 3 \\
\hline $180<x<=210$ & $10<x<=15$ & 1,6 & 2,4 \\
\hline $210<x<=240$ & $6<x<=10$ & 1,2 & 1,8 \\
\hline $240<x<=270$ & $3<x<=6$ & 0,8 & 1,2 \\
\hline $270<x<=300$ & $1<x<=3$ & 0,4 & 0,6 \\
\hline $300<x$ & $0<x<=1$ & 0 & 0 \\
\hline
\end{tabular}

Table 7. Inventory Turnover

Take the Best Score of Either 2 Variables [21]

\begin{tabular}{|c|c|c|c|c|}
\hline \multirow{2}{*}{\multicolumn{2}{|c|}{$\begin{array}{c}\mathbf{P P}=\mathbf{x} \\
\text { (hari) }\end{array}$}} & \multirow{2}{*}{$\begin{array}{l}\text { Perbaikan }=x \\
\quad \text { (hari) }\end{array}$} & \multicolumn{2}{|c|}{ Skor } \\
\hline & & & Infra & Non Infra \\
\hline & $x<=60$ & $x>35$ & 4 & 5 \\
\hline 60 & $<x<=90$ & $30<x<=35$ & 3,5 & 4,5 \\
\hline 90 & $<x<=120$ & $25<x<=30$ & 3 & 4 \\
\hline 120 & $<x<=150$ & $20<x<=25$ & 2,5 & 3,5 \\
\hline 150 & $<\mathrm{x}<=180$ & $15<x<=20$ & 2 & 3 \\
\hline 180 & $<x<=210$ & $10<x<=15$ & 1,6 & 2,4 \\
\hline 210 & $<x<=240$ & $6<x<=10$ & 1,2 & 1,8 \\
\hline 240 & $<x<=270$ & $3<x<=6$ & 0,8 & 1,2 \\
\hline 270 & $<x<=300$ & $1<x<=3$ & 0,4 & 0,6 \\
\hline 300 & $<x$ & $0<x<=1$ & 0 & 0 \\
\hline
\end{tabular}


Table 8. Total Assets Turn Over

Take the Best Score of Either 2 Variables [21]

\begin{tabular}{|c|c|c|c|}
\hline \multirow{2}{*}{$\begin{array}{c}\text { TATO }=\mathbf{X} \\
(\%)\end{array}$} & \multirow{2}{*}{$\begin{array}{c}\text { Perbaikan }=X \\
(\%)\end{array}$} & \multicolumn{2}{|c|}{ Skor } \\
\hline & & Infra & Non Infra \\
\hline $120<x$ & $20<x$ & 4 & 5 \\
\hline $105<x<=120$ & $15<x<=20$ & 3,5 & 4,5 \\
\hline $90<x<=105$ & $10<x<=15$ & 3 & 4 \\
\hline $75<x<=90$ & $5<x<=10$ & 2,5 & 3,5 \\
\hline $60<x<=75$ & $0<x<=5$ & 2 & 3 \\
\hline $40<x<=60$ & $x<=0$ & 1,5 & 2,5 \\
\hline $20<x<=40$ & $<$ & 1 & 2 \\
\hline$x<=20$ & $x<0$ & 0,5 & 1,5 \\
\hline
\end{tabular}

Table 9. Total Equity to Total Assets

Score Result from the Computed [21]

\begin{tabular}{|c|c|c|c|c|c|}
\hline \multicolumn{4}{|c|}{ TMS thd TA $(\%)=x$} & \multicolumn{2}{|c|}{ Skor } \\
\hline & & & & Infra & Non Infra \\
\hline & & $\mathrm{x}$ & $<\quad 0$ & 0 & 0 \\
\hline 0 & $<=$ & $\mathrm{x}$ & $<10$ & 2 & 4 \\
\hline 10 & $<=$ & $\mathrm{X}$ & $<20$ & 3 & 6 \\
\hline 20 & $<=$ & $\mathrm{x}$ & $<30$ & 4 & 7,25 \\
\hline 30 & $<=$ & $\mathrm{x}$ & $<40$ & 6 & 10 \\
\hline 40 & $<=$ & $\mathrm{x}$ & $<50$ & 5,5 & 9 \\
\hline 50 & $<=$ & $\mathrm{x}$ & $<60$ & 5 & 8,5 \\
\hline 60 & $<=$ & $\mathrm{x}$ & $<70$ & 4,5 & 8 \\
\hline 70 & $<=$ & $\mathrm{X}$ & $<80$ & 4,25 & 7,5 \\
\hline 80 & $<=$ & $\mathrm{x}$ & $<90$ & 4 & 7 \\
\hline 90 & $<=$ & $\mathrm{X}$ & $<100$ & 3,5 & 6,5 \\
\hline
\end{tabular}

The final step is to sum the total score that have been gotten from the eight financial ratios. Then determine the weighted score by dividing 70 as a denominator and multiply by 100 . The results of the weighted total score will determine the health rating of the company (whether included in AAA, AA, A, BBB, BB, B, $\mathrm{CCC}, \mathrm{CC}$, or $\mathrm{C}$ ).

\section{Result and Discussion}

Table 10. shows the calculation of Return on
Equity (ROE) that slightly increased in the last five years as the net income and the total equity significantly increased. Net income indicates how much profit that the company gains in the said year and it shows that the company takes more projects every year and they also maintain their capital as a proportion of the economic growth in the recent years. The increase in total equity mostly contributes by the increase in profits of the company. 
Table 10. Return on Equity Trend

Source: Author, 2016

\begin{tabular}{cccc}
\hline Year & Net Income & Total Equity & Return On Equity \\
\hline 2011 & $14,461,296,138$ & $196,554,566,052$ & $7.36 \%$ \\
\hline 2012 & $32,136,969,494$ & $406,722,080,312$ & $7.90 \%$ \\
\hline 2013 & $41,667,377,568$ & $497,389,457,880$ & $8.38 \%$ \\
\hline 2014 & $44,994,534,228$ & $542,393,174,073$ & $8.30 \%$ \\
\hline 2015 & $68,624,370,724$ & $608,668,576,712$ & $11.27 \%$ \\
\hline
\end{tabular}

Table 11. Return on Investment Trend Source: Author, 2016

\begin{tabular}{cccrc}
\hline Year & EBIT & Depreciation & Capital Employed & Return On Investment \\
\hline 2011 & $79,319,211,027$ & $65,980,947,514$ & $1,328,393,479,720$ & $10.94 \%$ \\
\hline 2012 & $144,019,135,852$ & $67,606,674,308$ & $1,459,817,587,844$ & $14.50 \%$ \\
\hline 2013 & $153,211,207,059$ & $68,564,403,843$ & $1,732,174,027,494$ & $12.80 \%$ \\
\hline 2014 & $126,619,000,000$ & $72,041,656,932$ & $2,136,560,021,845$ & $9.30 \%$ \\
\hline 2015 & $289,507,000,000$ & $81,993,003,756$ & $3,108,861,021,898$ & $11.95 \%$ \\
\hline
\end{tabular}

Table 11. exhibits the Return on Investment (ROI) that varied every year. The highest percentage is in the year of 2012 and the lowest was 2014. There was an increased as much as $3.56 \%$ from 2011 to 2012 and it decreased by $1.70 \%$ and $3.5 \%$ for 2013 and
2014. In 2015, the company regains their value by $2.65 \%$. Decrease of profits in 2014 was due to high competition in obtaining a new project in 2014.

(http://www.nindyakarya .co.id)

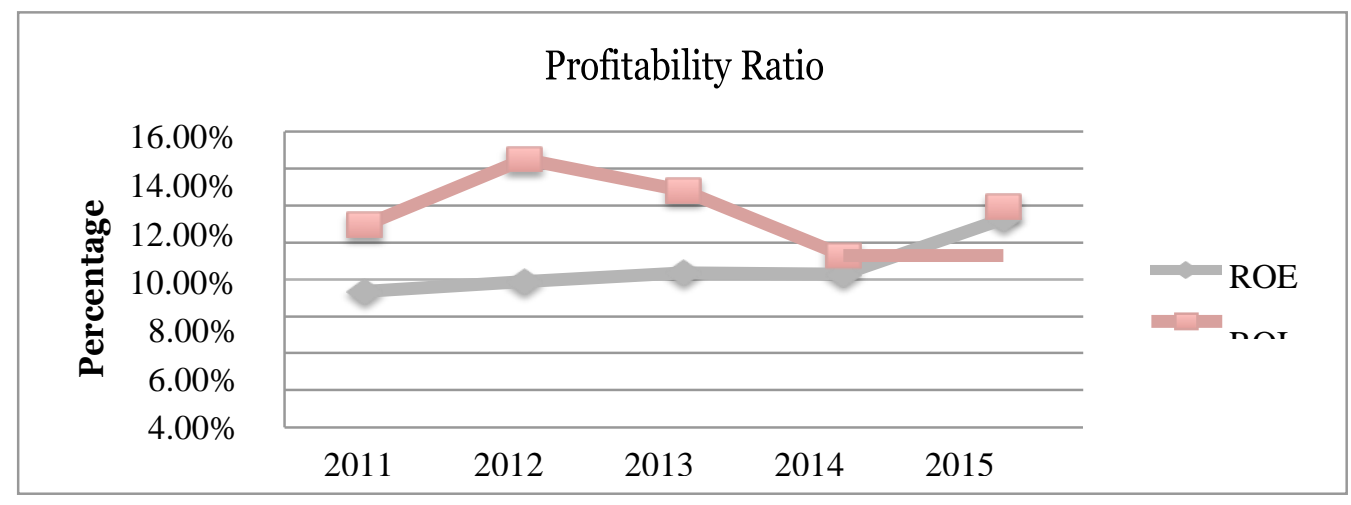

Figure 1. ROI and ROE Charts in Profitability Ratio Trend Source: Author, 2016

From the calculation above we can see the changes trends in Profitability. The value of ROI is higher than ROE, even though there's a variation in its trend. In 2014 there's a major decline for both ratios. This profitability ratio shows how well the company will generate its profit from their project realization.

In table below, the measurement of cash ratio and current ratio was being presented. The data indicates a large decrease of cash ratio trend in 2014. There's no significant pattern in the last five years, the number increased from $18.08 \%$ to $15.67 \%$ in 2012 , make it the second highest number. And then it was slightly decrease in 2013 by $3.61 \%$, the major declined is in 2014 which is $7.97 \%$ make it the lowest value of them all but then the number almost 
multiply from 2012 as much as $35.16 \%$ in 2015. The increase happened because of the company receive fund from new projects in the end of 2015 and the receipt of fund from projects that ended in 2015. While for the current ratio, it shows a sig- nificant inclined in the following five years and just a slightly decrease in 2013 by more or less $9 \%$. As current asset included cash and cash equivalent, the growth source was from it.

Table 12. Cash Ratio Trend

Source: Author, 2016

\begin{tabular}{cccc}
\hline Year & Cash and Cash Equivalent & Current Liabilities & Cash Ratio \\
\hline 2011 & $116,024,962,903$ & $1,086,626,316,432$ & $10.68 \%$ \\
\hline 2012 & $204,223,258,166$ & $1,129,654,983,916$ & $18.08 \%$ \\
\hline 2013 & $234,121,874,642$ & $1,493,979,530,308$ & $15.67 \%$ \\
\hline 2014 & $106,586,358,717$ & $1,589,721,522,315$ & $6.70 \%$ \\
\hline 2015 & $843,833,788,459$ & $2,399,819,092,850$ & $35.16 \%$ \\
\hline
\end{tabular}

Table 13. Current Ratio Trend Source: Author, 2016

\begin{tabular}{cccc}
\hline Year & Current Assets & Current Liabilities & Current Ratio \\
\hline 2011 & $1,185,934,694,127$ & $1,086,626,316,432$ & $109.14 \%$ \\
\hline 2012 & $1,315,900,413,905$ & $1,129,654,983,916$ & $116.49 \%$ \\
\hline 2013 & $1,574,043,681,959$ & $1,493,979,530,308$ & $105.36 \%$ \\
\hline 2014 & $1,846,056,476,719$ & $1,589,721,522,315$ & $116.12 \%$ \\
\hline 2015 & $2,810,929,462,693$ & $2,399,819,092,850$ & $117.13 \%$ \\
\hline
\end{tabular}

Figure 2. draws a trend for liquidity ratio which contain both cash ratio and current ratio. There was a large gap in the percentage of both ratios. According to Daryanto et al (2018), Current ratio will show the basic requirement to determine the liquidity of the company. In the other side, cash ratio indicates cash guaranteed by the company for the stated number of current liabilities. Therefore, that they can still maintain their liquid condition and didn't have short-term financial problems.

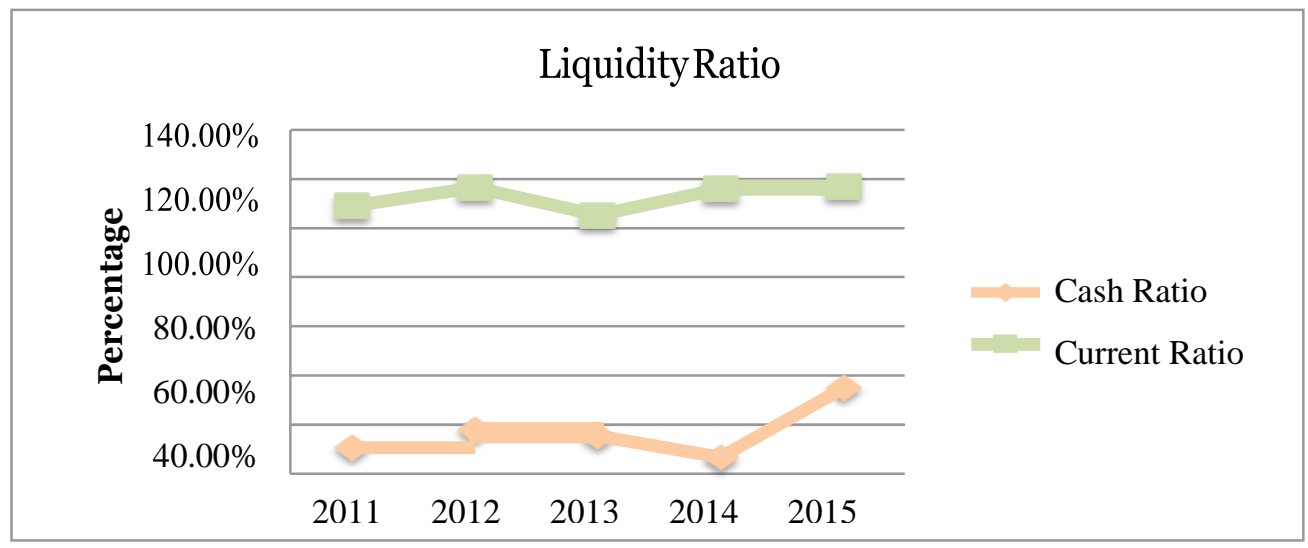

Figure 2. Cash Ratio and Current Ratio Charts in Liquidity Ratio Source: Author, 2016 
Table 14 and table 15 exhibit the number of Collection Periods and Inventory Turnover of PT. Nindya Karya (Persero) in days. The collection periods indicate a varied result pattern that once again the major decline and the lowest number were in 2014. It is because the account receivables decreased significantly while the sales revenue was slightly increased. The highest number was shown in 2013 which is 30 days, and following with the highest sales revenue and total account receivables in the last five years. As for Inventory Turnover, there was significant gain every year till 2014 and just a slight decrease in 2015 by 1 day. the changes in the account receivables was due to an increase or decrease of the new project and the company still waiting for the final payment from the owner and an increase in inventories is caused by the need of the company for additional inventories for new projects.

Table 14. Collection Periods Trend Source: Author, 2016

\begin{tabular}{cccc}
\hline Year & Total Account Receivables & Sales Revenue & $\begin{array}{c}\text { Collection Periods } \\
\text { (in days) }\end{array}$ \\
\hline 2011 & $46,772,258,286$ & $857,561,973,648$ & 20 \\
\hline 2012 & $77,329,838,368$ & $1,611,515,596,799$ & 18 \\
\hline 2013 & $146,868,231,084$ & $1,809,898,548,607$ & 30 \\
\hline 2014 & $86,952,547,058$ & $1,881,416,850,299$ & 17 \\
\hline 2015 & $212,822,592,327$ & $3,613,197,034,660$ & 21 \\
\hline
\end{tabular}

Table 15. Inventory Turnover Trend Source: Author, 2016

\begin{tabular}{cccc}
\hline Year & Total Inventories & Sales Revenue & $\begin{array}{c}\text { Inventory Turnover } \\
\text { (in days) }\end{array}$ \\
\hline 2011 & $7,773,299,967$ & $857,561,973,648$ & 3 \\
\hline 2012 & $34,767,585,548$ & $1,611,515,596,799$ & 8 \\
\hline 2013 & $58,536,743,481$ & $1,809,898,548,607$ & 12 \\
\hline 2014 & $85,746,713,567$ & $1,881,416,850,299$ & 17 \\
\hline 2015 & $155,570,719,704$ & $3,613,197,034,660$ & 16 \\
\hline
\end{tabular}

Table 16 below refers to Total Asset Turnover that increased from $64.56 \%$ in 2011 to $110.39 \%$ in 2012 and it slightly decreased in 2013 to $104.49 \%$ and reduce to the lowest number, $88.06 \%$ in 2014 , but it inclined to $116.22 \%$ in 2015 . The major declined was due to the increase in capital employed while the sales revenue just slightly rises.

Table 16. Total Asset Turnover Trend Source: Author, 2016

\begin{tabular}{cccc}
\hline Year & Sales Revenue & Capital Employed & TATO \\
\hline 2011 & $857,561,973,648$ & $1,328,393,479,720$ & $64.56 \%$ \\
\hline 2012 & $1,611,515,596,799$ & $1,459,817,587,844$ & $110.39 \%$ \\
\hline 2013 & $1,809,898,548,607$ & $1,732,174,027,494$ & $104.49 \%$ \\
\hline 2014 & $1,881,416,850,299$ & $2,136,560,021,845$ & $88.06 \%$ \\
\hline 2015 & $3,613,197,034,660$ & $3,108,861,021,898$ & $116.22 \%$ \\
\hline
\end{tabular}




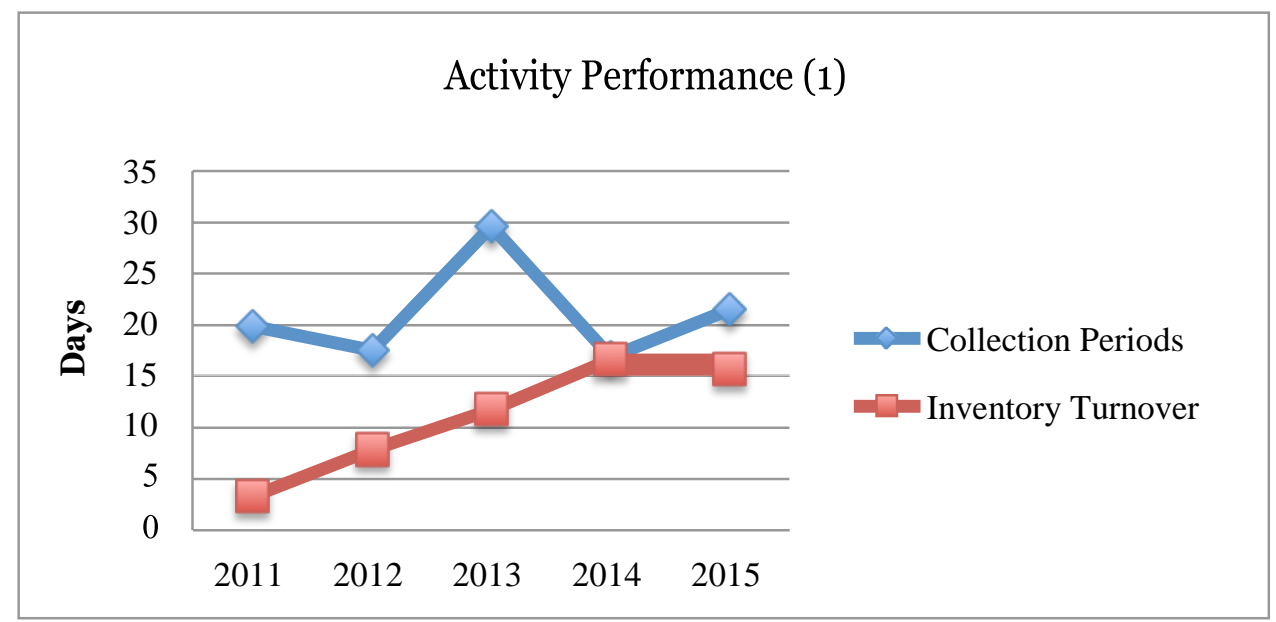

Figure 3. CP and IT Charts in Activity Performance (1) Source: Author, 2016

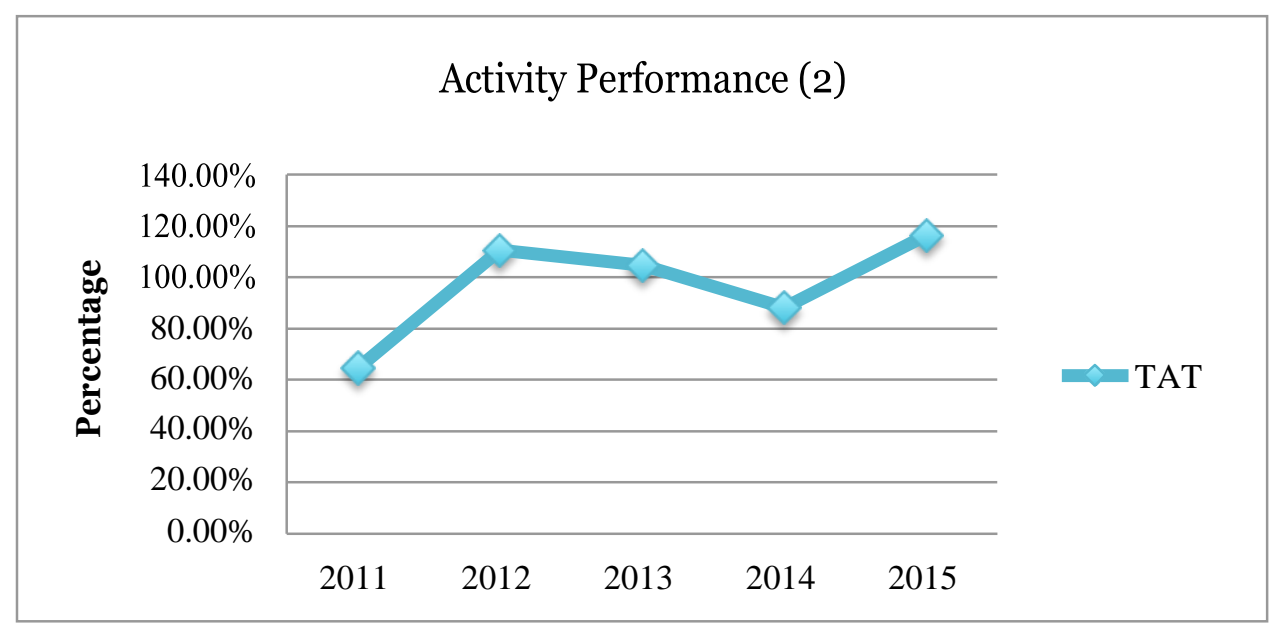

Figure 4. TATO Chart in Activity Performance (2) Source: Author, 2016

Figure 3 and figure 4 pointed out the activity performance of the company from its collection periods, inventory turnover and total asset turnover. The significant decreased in 2014 was shown in changes trend of total asset turnover and collection periods. PT. Nindya Karya (Persero) has a high number in Inventory turnover which means that the operation activity of the company was running efficiently.
The total equity to total asset ratio calculation can be seen in table 17. The number was significantly rising from 2011 to 2013 , from $14.29 \%$ to $23.56 \%$. Then the trend was shown a decrease that started from 2013 to 2015. The decline in 2015 was as much as $4.24 \%$ from $21.64 \%$ in 2014 to $17.40 \%$ in 2015 . This is caused by the substantial increase in both total equity and total asset, but the lowest number is still $14.29 \%$ in 2011. 
Table 17. Total Equity to Total Asset Trend Source: Author, 2016

\begin{tabular}{cccc}
\hline Year & Total Equity & Total Assets & $\begin{array}{c}\text { Total Equity to Total } \\
\text { Assets Ratio }\end{array}$ \\
\hline 2011 & $196,554,566,052$ & $1,375,778,752,377$ & $14.29 \%$ \\
\hline 2012 & $406,722,080,312$ & $1,718,317,998,303$ & $23.67 \%$ \\
\hline 2013 & $497,389,457,880$ & $2,111,418,657,138$ & $23.56 \%$ \\
\hline 2014 & $542,393,174,073$ & $2,506,191,485,702$ & $21.64 \%$ \\
\hline 2015 & $608,668,576,712$ & $3,498,330,251,500$ & $17.40 \%$ \\
\hline
\end{tabular}

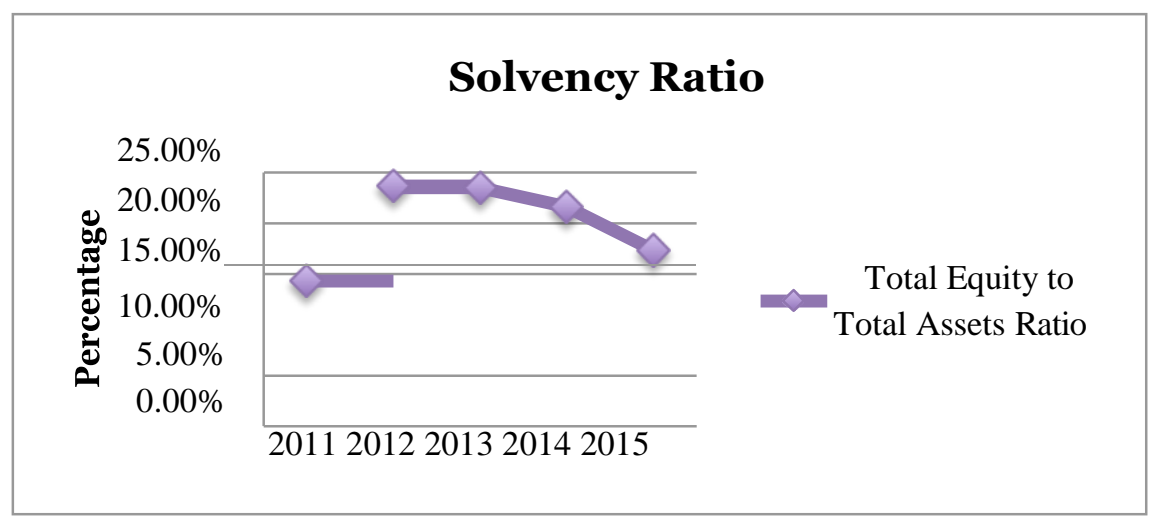

Figure 5. Total Equity to Total Asset in Solvency Ratio Source: Author, 2016

The figure above shows the solvency ratio trend that contains total equity to total asset ratio. As the total equity and total asset increased every year, it doesn't mean that the ratio will increased significantly. The solvency ratio explains the indicator to measure the financing source of debt as a constant financial payment (Trian N.,2015)

Table 18. Summary of the Financial Ratio Source: Author, 2016

\begin{tabular}{lrrrrr}
\hline \multirow{2}{*}{ Financial Ratio } & \multicolumn{5}{c}{ Y e a r } \\
\cline { 2 - 6 } Profitability & $\mathbf{2 0 1 1}$ & $\mathbf{2 0 1 2}$ & $\mathbf{2 0 1 3}$ & $\mathbf{2 0 1 4}$ & $\mathbf{2 0 1 5}$ \\
\hline ROI & & & & & \\
\hline ROE & $10.94 \%$ & $14.50 \%$ & $12.80 \%$ & $9.30 \%$ & $11.95 \%$ \\
\hline Liquidity & $7.36 \%$ & $7.90 \%$ & $8.38 \%$ & $8.30 \%$ & $11.27 \%$ \\
\hline Cash Ratio & & & & & \\
\hline Current Ratio & $10.68 \%$ & $18.08 \%$ & $15.67 \%$ & $6.70 \%$ & $35.16 \%$ \\
\hline Activity & $109.14 \%$ & $116.49 \%$ & $105.36 \%$ & $116.12 \%$ & $117.13 \%$ \\
\hline Collection Period & & & & & 17 \\
\hline Inventory Turnover & 20 & 18 & 30 & 17 \\
\hline Total Assets Turnover & 3 & 8 & 12 & 16 \\
\hline Solvency & $64.56 \%$ & $110.39 \%$ & $104.49 \%$ & $88.06 \%$ & $116.22 \%$ \\
\hline Total Equity to Total Assets & $14.29 \%$ & $23.67 \%$ & $23.56 \%$ & $21.64 \%$ & $17.40 \%$ \\
Ratio & & & & & \\
\hline
\end{tabular}


The summary of the measurement of financial ratio analysis for five years periods from 2011 to 2015 can be seen in the above table. The result was varied and from some of the ratios such as Return on
Investment, Cash Ratio, Collection Period and Total Asset Turnover, the major decline was happening in 2014, but the lowest total numbers was in 2011, while the highest was shown in 2015.

Table 19. Total Weight and Scoring Source: Author, 2016

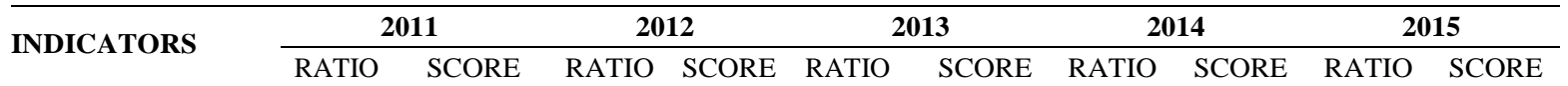

\begin{tabular}{lrrrrrrrrrr}
\hline ROE (\%) & 7.36 & 10 & 7.9 & 10 & 8.38 & 12 & 8.3 & 12 & 11.27 & 16 \\
\hline ROI (\%) & 10.94 & 9 & 14.5 & 12 & 12.8 & 10.5 & 9.3 & 9 & 11.95 & 9 \\
\hline Cash Ratio (\%) & 10.68 & 2 & 18.08 & 3 & 15.67 & 3 & 6.7 & 1 & 35.16 & 5 \\
\hline Current Ratio & 109.14 & 3 & 116.49 & 4 & 105.36 & 3 & 116.12 & 4 & 117.13 & 4
\end{tabular}
$(\%)$

\begin{tabular}{lcccccccccc}
\hline $\begin{array}{l}\text { Collection } \\
\text { Period (Days) }\end{array}$ & 20 & 5 & 18 & 5 & 30 & 5 & 17 & 5 & 21 & 5 \\
\hline $\begin{array}{l}\text { Inventory } \\
\text { Turnover }\end{array}$ & 3 & 5 & 8 & 5 & 12 & 5 & 17 & 5 & 16 & 5
\end{tabular}

\begin{tabular}{|c|c|c|c|c|c|c|c|c|c|c|}
\hline TATO (\%) & 64.56 & 3 & 110.39 & 4.5 & 104.49 & 4 & 88.06 & 3.5 & 116.22 & 4.5 \\
\hline $\begin{array}{l}\text { Total Equity to } \\
\text { Total Assets } \\
\text { Ratio (\%) }\end{array}$ & 14.29 & 6 & 23.67 & 7.25 & 23.56 & 7.25 & 21.64 & 7.25 & 17.4 & 6 \\
\hline Total Score & & & & 50.75 & & 49.75 & & 46.75 & & 54.50 \\
\hline
\end{tabular}

Table 19 gives the information of the scoring for each ratio in 2011 to 2015 that was based on the decree of Indonesia's Ministry of Stated-Owned Enterprises No. KEP- 100/MBU/2002. The total score was increased from 43 to 50.75 in 2012 , and then it started to decrease to 49.75 in 2013 following by 46.75 in 2014 . It increased in 2015 as much as 54.50. The total scores then will be used to calculate the total weight by dividing it with the designated total weight (70) and multiply it by $100 \%$. The value of the total weight will be used to assess the level of healthiness of PT. Nindya Karya (Persero) in table 20 below. The category of the company is still in healthy condition and increased from 2011 which is less healthy because it has the lowest number in total weight in the last 5 years period. 
Table 20. Health Indicator for Five Years Period Source: Author, 2016

\begin{tabular}{cccccc}
\hline Year & Total Score & Total Weight & Value & Level & Category \\
\hline 2011 & 43.00 & 61.43 & $50<\mathrm{TS} \leq 65$ & $\mathrm{BBB}$ & Less Healthy \\
\hline 2012 & 50.75 & 72.50 & $65<\mathrm{TS} \leq 80$ & $\mathrm{~A}$ & Healthy \\
\hline 2013 & 49.75 & 71.07 & $65<\mathrm{TS} \leq 80$ & $\mathrm{~A}$ & Healthy \\
\hline 2014 & 46.75 & 66.79 & $65<\mathrm{TS} \leq 80$ & $\mathrm{~A}$ & Healthy \\
\hline 2015 & 54.5 & 77.86 & $65<\mathrm{TS} \leq 80$ & $\mathrm{~A}$ & Healthy \\
\hline
\end{tabular}

\section{Limitation}

This study only measures the financial performance of one company in construction industry and it is limited only from the financial aspect of the company. It is best to compare it with not only other state-owned company but also private company, so that we can see more general result of the financial performance of PT. Nindya Karya (Persero) and its position against the competitors in the construction industry. Additionally, the measurement and the scoring of the financial health condition were only based on the decree No. KEP-100/MBU/2002 issued by Indonesia's Ministry of Stated-Owned Enterprises, to get more comprehensive and board result it is suggested to also use other financial ratio besides those eight ratios.

\section{Conclusion and Recommendation}

Based on the financial performance evaluation and data analysis, it can be concluded that all the financial ratio tends to increase in the last five years, even though in 2014 Return on Investment, Cash Ratio, Collection Period and Total Asset Turnover decreased significantly, the total weight is still high so that the company can still manage their level performance.

PT. Nindya Karya (Persero) is still in a good condition. The performance improves from "BBB" level which is less healthy in 2011 to " $A$ " level which is Healthy in the next 4 years that means the company have the ability to maintain their good financial performances in the midst of high competition in the market and they will likely to improve in the future.

This result can be used as future references for PT. Nindya Karya (Persero) as a consideration in the decision-making process of the management and for arranging their strategy to maintain and improving their performance in the competitive market and achieve a sustainable growth.

PT. Nindya Karya (Persero) should manage their financial aspect and increase the company's level of healthiness to AA or AAA so that the financial performance can improve. They also need to raise their quality to compete in the market for gaining more new projects and it will directly increase the sales revenue and its profits along with return on equity and return on investment ratios that can still be maximized. They can also increase the productivity with optimizing resources, control their production cost, make the account receivables collection more effective to gain more profits and decrease the financing expense in loan so the total liabilities could be decreased.

\section{References}

Cheah, C., Garvin, M. \& Miller, J. (2004) Empirical study of strategic performance of global construction firms. Journal of Construction Engineering and Management, 130(6), 808-817. 
Daryanto, W. M. \& Nurfadilah, D. (2018). Financial performance analysis before and after the decline in oil production: case study in Indonesian oil and gas industry. International Journal of Engineering \& Technology, 7(3.21), 10-15.

Kusumawardani, S. D. (2014). Analisis rasio keuangan untuk menilai kinerja keuangan Badan Usaha Milik Negara (studi pada perusahaan BUMN yang terdaftar di BEI periode 2010-2012). Fakultas Ilmu Administrasi Universitas Brawijaya.

Lukmana, M. \& Subiakto, S. (2013). Financial performance analysis of PT. Waskita Karya related to its initial public offering stock price and future prospect. The Indonesian Journal of Business Administration, 2(12), 1451-1465.

Nindya Karya, PT. (Persero) (2017). Laporan Keuangan Tahunan. accessed Mar 20, 2017, from http://www.nindyakarya. co.id

Sapri, M., Stephen, K. \& Martin, B. (2007). Evaluating financial ratio in construction industry: a case study of Indonesia firms. Accessed Mar 25, 2017, from http://eprints.qut.edu.au

Trian, N. (2015). Analisis rasio keuangan untuk menilai kinerja BUMN pada PT. Adhi Karya (Persero) Tbk. tahun 2012-2014. Fakultas Ekonomi Universitas Negeri Yogyakarta.

Sudarto et al. (2005). Pengembangan sistem bisnis perusahaan jasa konstruksi di indonesia dengan menggunakan knowledge base management system. Accessed Mar 25, 2017, from https://www.researchgate.net/publica tion/265864760.

Wulandari \& Yulia. (2010) Financial performance assessment of PT Semen Gresik (Persero) Tbk in comparison with other cement companies locally and globally. SBM ITB.

Wicak, L., Saifi, M. \& Zahroh, Z. (2015) Analisis tingkat kesehatan perusahaan dari aspek keuangan berdasarkan Keputusan Menteri BUMN Nomor: Kep-100/MBU 12002. Journal Administrasi Bisnis, 26(1). 